\title{
No Panacea for Success: Member Activism, Organizing and Union Renewal
}

\author{
Robert Hickey \\ Master of Industrial Relations Program, Queen's University \\ Sarosh Kuruvilla \\ School of Industrial and Labor Relations, Cornell University \\ Tashlin Lakhani
}

Max M. Fisher College of Business, The Ohio State University

\begin{abstract}
The precipitous decline in union density and influence around the world has spawned a growing body of scholarship on union renewal. While this literature evidences lively debates regarding the efficacy of different renewal strategies, many argue that the path to renewal is paved through increased member activism. In this article, we question that premise. We examine the importance of rank-and-file union member activism in 44 cases of organizing campaigns in the United States and in the UK. Our review of these cases reveals little support for the notion that member activism is indispensable to union renewal in general, and successful organizing campaigns in particular. Our findings provide additional insight into the debate over top-down and bottom-up strategies for renewal, and raise several questions for future research regarding when, under what conditions, and under what rules worker activism matters for labour union renewal.
\end{abstract}

\section{Introduction}

Efforts by unions to reverse the precipitous decline of density and influence in the United States, the UK and around the world have prompted a growing body of scholarship on union renewal (e.g. Fairbrother 2000; Fairbrother and Yates 2003; Kumar and Schenk 2006; Turner et al. 2001). While there is considerable debate among scholars regarding the strategies unions should take to renew, many agree that the path to renewal is paved through increased member participation and mobilization. A number of scholars, for example, have argued that rank-and-file activism is necessary for union renewal and at the very least, union strength (Fairbrother 1989; Gallagher and Strauss 1991: 154-5; Kelly 1998; Kumar and Schenk 2006; Metzgar 1991; Muehlenkamp 1991; Stinson and Ballantyne 2006). The notion that 
member activism is necessary for union renewal is also manifested in initiatives such as the Activism Academy, a new training programme recently launched by the Trades Union Congress (TUC) in the UK aimed at building stronger unions by increasing union member activism. In a recent review, Gall and Fiorito (2007) suggest that 'activism among lay members is quite nearly, if not in fact, a fundamental issue for all conceptions of union renewal' (p. 11). This article questions that fundamental assumption and explores the relationship between rank-and-file activism and union renewal.

We know what makes union members more active in their unions from over 25 years of research on union commitment, union satisfaction and union participation (see Fiorito et al. 1988; Fullagar et al. 2004; Gordon et al. 1980; Sverke and Kuruvilla 1996). The relatively recent union renewal literature, on the other hand, is less clear as to the determinants of union renewal. Assessing the role of member activism, as well as broader collective mobilization in union renewal efforts is hampered by the diverse, and at times contradictory, conceptualizations of what constitutes union renewal. Union renewal has come to mean many things (Fiorito 2004; Heery 2003), including new organizing success or increased union density (measures of outcome) and revitalization in terms of new union strategies (e.g. political and legislative action, coalition building, transnational networking), new levels of mobilization, more member engagement and more union democracy (measures of process).

There is reason, we argue, to be skeptical regarding the claim that member activism is fundamental to union renewal. Unions are after all voluntary organizations and decades of research on voluntary organizations in other spheres (Olson 1965; Scott 1957; Walsh and Warland 1983) suggest that most voluntary organizations have a core of activists and a large number of free-riders. Empirical studies also show that member activism in unions remains weak at best (Gall and Fiorito 2007; Hartley 1996; Kuruvilla and Fiorito 1994; Nissen 1998). Even in those cases where an 'organizing model' has been adopted, it is not at all clear that member activism is either sufficient for union renewal or that reliance on paid union staff has diminished (Gall 2005; Wills 2003).

Our approach in this article is novel. To examine the role of activism (defined as rank-and-file union members taking greater responsibility, initiative) and activity rather than reliance on paid union staff (Gall and Fiorito 2007: 4) in union renewal, we focus on cases of union organizing. In this way, we attempt to avoid the circular argument that places member activism on both sides of the renewal equation. That is, one cannot assess the role of member activism if union renewal is seen as the process of generating greater member commitment and activism within the organization. Likewise, to evaluate the impact of member activism, we construct the dependent variable in a way that provides a measurable assessment of union renewal success - an organizing campaign that results in employer 
recognition, either voluntarily or through statutory certification procedures. We ask how important union member activism is to that success. In order to do so, we 'stand on the shoulders of giants', relying on the published work of scholars who have studied union organizing cases at great depth with a view to identifying the key determinants of organizing success. 'If member activism is indeed critical to successful union renewal efforts, we should see that across the population of cases.

Below, we briefly review the (very) limited literature on the linkage between research on member activism and research on union renewal, followed by a discussion of our methods and results.

\section{Linkages between member activism and union renewal}

Recognizing that much of the union renewal literature focuses on models of unionism in which member commitment and active participation are key (in contrast to a servicing model in which members are the passive recipients of union representational services), Gall and Fiorito (2007) call for a closer linkage between two hitherto unconnected academic literatures, i.e. union commitment and union renewal. Gordon et al.'s (1980) effort to define and measure union commitment prompted a large number of studies in the 1980s and 1990s. In general terms, this stream of literature identifies two types of member commitment to their unions, a calculative-based commitment and value-based commitment (Bamberger and Kluger 1999; Sverke and Kuruvilla 1996). Member commitment to unions is a function of several variables, including beliefs about unionism, socialization and job satisfaction (see Fullagar et al. 2004 for a review), but it is the consequences of union commitment that are more germane here. The research is fairly unambiguous that the greater a member's commitment to the union, the greater the declared willingness to work for the union, and the greater the actual participation and activism (Bamberger and Kluger 1999; Fullagar et al. 2004). Gordon's seminal work would appear to suggest that current union renewal efforts are fundamentally linked to union commitment:

Since the ability of union locals to attain their goals is generally based on the members' loyalty, belief in the objectives of organized labor, and willingness to perform services voluntarily, commitment is part of the very fabric of unions. (Gordon et al. 1980: 480)

Union commitment is therefore the lifeblood of the organization, generating the willingness of lay members to voluntarily engage in union activities. In this way, member activism (as used in this article) 
goes beyond the limited forms of administrative participation, such as voting on a collective agreement, or passive participation (McShane 1986).

With much of the union renewal literature's emphasis on activism, one would assume that the two streams of academic literature would have a well-established connection. However, as several scholars have pointed out (Gall and Fiorito 2007; Snape et al. 2000), the union renewal literature has developed with little regard to the established research on union commitment and participation. Part of the current difficultly in building bridges between these two literatures now stems from the diversity in the conceptualizations of union renewal.

Some scholars define union renewal as 'programs and policies to increase the internal strength of the union by building stronger union connections with members and increasing their engagement in union activities' (Stinson and Ballantyne 2006: 145). This stream in the union renewal literature focuses on the relationship between the union and its members (Fairbrother 1989). Renewal, in this perspective, stems from a greater willingness on the part of lay members to participate in core union activities (Kumar and Schenk 2006) and broader social justice campaigns (Turner and Hurd 2001).

Thus, union renewal is viewed as a process of member re-engagement and increased commitment and participation. However, the continuing decline of union density in most countries has prompted some scholars to question the efficacy of the organizing model and other mobilization-based concepts of union renewal (De Turberville 2004).

In the other major stream of the union renewal literature, scholars have tended to focus more on the outcomes of union revitalization efforts (Behrens et al. 2004; Bronfenbrenner and Hickey 2004; Milkman 2006). Renewal research focused on the measurable outcomes of membership growth, political influence and sustainable collective bargaining structures have identified a host of strategic and institutional factors that receive less consideration by mobilization theorists (Kelly 1998). For example, to scholars in this stream, the factors contributing to success include leadership-driven ones, such as the infusion of 'new blood' at the leadership level and the adoption of innovative tactics (Voss and Sherman 2000). However, even in the managerial theory of union renewal (Heery 2003), union commitment and member participation are still generally considered essential for success.

While these two streams in the union renewal literature are not mutually exclusive, they have sparked an ongoing debate over the role and effectiveness of bottom-up versus top-down strategies. Scholars who emphasize the role of rank-and-file activism in union renewal efforts suggest that innovation is driven by member participation (Tait 2005), especially when faced with the bureaucratic inertia of entrenched union officials (Fairbrother 1989; Parker and Gruelle 1999). In contrast, the other 
side of the debate tends to focus on strategic choices made by union leaders (Heery 2003; Lerner 2003). The controversy surrounding the use of employer neutrality agreements in union organizing campaigns reflects one contentious dimension of this ongoing debate (Hurd 2008). A growing number of scholars suggest that union renewal demands a 'third way', a combination of top-down and bottom-up strategies (Bach and Givan 2008; Bronfenbrenner and Hickey 2004; Milkman 2006). This article contributes to this debate by examining the centrality of member activism in cases of union organizing campaigns.

Increased union organizing is of course not the only dimension in union renewal. The union renewal literature identifies several strategic mechanisms for renewal: organizing, political action, coalition building, labour management partnerships, and transnational networking (Hurd et al. 2003; Kelly and Frege 2004; Kumar and Schenk 2006; Mareschal 2006). We focus on organizing here because much of the renewal literature highlights the importance of activism in organizing, and because it is a good measure of renewal.

There is considerable research on the determinants of union organizing success in the United States that we will not review here (see Bronfenbrenner 1997; Eaton and Kriesky 2001; Juravich and Hilgert 1999; Milkman 2006; and Riddell 2004 for more detail). More significant for our study here is the research on the critical impact that employer resistance has on union organizing success (Freeman and Kleiner 1990; Martinello and Yates 2004). Early research by Bronfenbrenner (1997) showed that unions could improve their chances of winning an NLRB election through the use of rank-and-file intensive tactics such as house calls and other one-on-one forms of communication. Subsequent research (Bronfenbrenner and Hickey 2004; Bronfenbrenner and Juravich 1998) has built on this framework, but shown that house calls alone are not enough in the face of an increasingly hostile organizing environment. Bronfenbrenner and Hickey argue that increasing the likelihood of organizing success requires that unions adopt comprehensive strategies, combining workplace activism with sufficient organizational resources, strategic leadership and external sources of leverage.

Note that member activism, as established in the union commitment literature, is distinct from the conceptual tradition of rank-and-file intensive tactics (Bronfenbrenner 1997; Bronfenbrenner and Juravich 1998), which may involve paid union staff organizers meeting with workers on a one-on-one basis and conducting house calls. Likewise, the practice of rank-and-file members who take a leave from their regular employment to work for the union on a temporary, paid for lost time basis, does not fit with our concept of member activism. Organizing tactics consistent with our concept of member activism are reflected in such tactics as an active and representative organizing committee (Bronfenbrenner and Hickey 2004) and similar voluntary actions based on union commitment. Despite 
the well-established research into the importance of union strategies in general, and workplace activism in particular, the adoption of such tactics remains limited among US unions. In their study of US organizing tactics, for example, Bronfenbrenner and Hickey (2004: 28) found that only 26 per cent of the campaigns in their sample had an active representative rank-and-file committee. Similarly, the adoption of grassroots organizing strategies remains limited in the UK context (Heery et al. 2003). While Heery and his colleagues found that an activist orientation was associated with improved recruitment and organizing outcomes, only 28 per cent of the unions in their national survey reported using a member organizing committee (p. 64). Thus, our conception of member activism is the voluntary engagement of members in union activities and organizing that goes beyond their administrative participation in union meetings.

\section{Methodology}

Given that union renewal has been conceptualized both as a consequence of member activism and as a determinant of it, we try to examine the first part of this linkage. We define successful union renewal as those instances where organizing efforts by unions have resulted in membership gains through union recognition (via statutory certification procedures or voluntary recognition by the employer). We use recognition to measure union success even though other campaign outcomes may provide evidence of success without formal employer recognition. For example, Brooks (2005) described the SEIU Local 880 childcare provider campaign as a success because the union won a pay increase and numerous grievances over back pay. Employer recognition is a more appropriate measure of success since it establishes a formal collective bargaining relationship and a more stable source of union membership.

Our task then was to find published case studies of organizing campaigns. An examination of English language books, anthologies and peer-reviewed journals revealed 32 detailed case studies of successful union organizing campaigns. We excluded many studies that did not meet our criteria of successful campaigns. For example, we excluded a number of otherwise insightful case studies that focus only on one particular aspect of the campaign and therefore fail to provide a complete profile of factors influencing the outcome of the union organizing effort. For example, Peters and Merrill (1998) document the successful campaign by HERE to organize Carson International, a concessions vendor at O'Hare International Airport. While the authors provide background and context to the union's campaigning, the case analysis focuses almost exclusively on the role of clergy and religious persons in the campaign. As such, the case description and analysis made it impossible to accurately 
assess the role and importance of member activism. Similarly, Penney (2004) describes four union organizing campaigns in the health sector, two successful and two unsuccessful, but the cases are used to illustrate anti-union attitudes and behaviours. In this study, the case descriptions did not provide enough data to assess member activism. A number of case studies we excluded examine campaigns that were still ongoing, and the eventual outcome was unclear (Gall 2005; Heery et al. 2000).

We also excluded several valuable studies that placed organizing within the larger arsenal of renewal tactics: political action, coalition building, labour management partnership, organizational change and international solidarity (Hurd et al. 2003; Kelly and Frege 2004). These important contributions to the union renewal literature do not tend to provide the type of detailed case study analysis necessary for examining the role of member activism in organizing success. Finally, the different organizing traditions between the United States and the UK, especially the centrality of 'in fill' recruitment drives in the UK, limited the number of cases in our final pool.

We realize that 32 detailed case studies is not a large number given that, at least in the United States, unions win over 1,000 representation elections each year (NLRB 2004-2006). i. As noted, however, we are dependent on instances where academics have published detailed case studies on successful organizing campaigns and given that, 32 is a pretty large number! The cases consisted of 23 successful organizing campaigns from the United States and nine from the UK, drawn from a wide range of industries, between 1989 and 2007. To account for differences in the legal frameworks and certification procedures between the United States and the UK, we have focused primarily on cases of 'greenfield' organizing campaigns; workplaces where the union does not already have recognition from the employer.iii

In each case study, we examined the following issues: To what extent did the case writers clearly articulate the factors behind the success of the organizing campaign? Did the case writers view member activism as an important factor or not? In 24 case studies, the case writers themselves ranked the key factors for success, which we subsequently used. For the balance eight cases, two of the authors of this article independently rank-ordered the top three factors critical to organizing success based on a detailed examination of the information provided in the case studies. In all but two instances, the rankings of the factors critical to organizing success by the two authors were similar. In those two instances, the two authors discussed their rankings and arrived at a consensus. We do acknowledge that these rankings rely heavily on the interpretation of the qualitative case research by the case writers regarding the role played by member activism as well as our interpretation of the role of member activism in the published case studies. Thus, subjectivity and judgement do play a key role in our analysis 
(unavoidable given that this is an interpretive exercise), despite our effort to limit, in part, the role of judgement and subjectivity by having the two co-authors rank the importance of factors in some cases separately.

The decision rule we followed was that if member activism was ranked as the first or second most important factor in organizing success in each case, we classified that as a case with significant member activism (SMA), indicating strong support for the argument that member activism is important for union renewal. If member activism was ranked as the third most important factor, we classified that as a case with partially significant member activism (PSMA), indicating partial support for the proposition that member activism is important for union renewal. If member activism did not figure in the top three factors critical to organizing success, we classified that as a case with insignificant member activism (IMA), indicating a lack of support for the proposition that member activism is important for union renewal. We realize that this decision rule is not perfect. For example, if our rule was that we would classify SMA only if member activism was ranked first (and not second), we run the risk of understating the importance of activism. Our current scheme runs the risk of overstating the importance of member activism. We also do not know the qualitative difference or ordinal distance between member activism classified as SMA or PSMA. But given that this is an explorative study regarding the importance of member activism, we had to use some decision rule to classify the various cases.

In addition, we tried to assess the importance of contextual information that could have affected the outcome of the case. We looked closely at the industry, the location and at whether the employer response was adverse (which may help to account for low or high levels of activism). Finally, to further understand the role of activism in organizing (and to validate our results), we went back to the literature to look for cases of union organizing campaigns that failed to result in employer recognition. Because we could not assess whether member activism was a significant factor in union renewal (given that our definition of renewal here was a successful organizing campaign), we instead examined whether the level of member activism in these failed cases was high or low as reported by the case writer. We identified only 12 such cases in the literature (apparently scholars are more likely to write-up cases of success!). Four of these cases were from the United States, and eight from the UK, and they occurred during the 2003-2007 time period.

\section{Results}

Table 1 presents our summary of the successful case studies. Rows 1-7 of Table 1 provide basic case information including the author of the case study, the year(s) of the campaign, the sector/industry, the 
union involved, the location and the job type (i.e. blue collar, white collar or service). Row 8 contains an abbreviated description of the motivation for the campaign. Although we wanted to include other campaign characteristics in row 8 to contextualize our abbreviated description for the motivation for each campaign, space limitations prevent us from doing so. We therefore encourage interested readers to refer to those cases. Rows 9 and 10 provide the employer's response to the campaign and the outcome of the campaign (i.e. whether statutory or voluntary recognition was granted). Row 11 reflects the rank ordering of the factors critical to organizing success. Based on the information in row 11, in row 12 we characterize the role of member activism in the campaign as significant, partially significant or insignificant.

The most crucial finding here can be seen in row 12 of Table 1, which suggests that union member activism is neither consistently necessary nor consistently sufficient for union renewal. Member activism was found to be the significant ingredient in the success of the organizing campaign (recall that importance is high if it was ranked first or second) in 18 of the 32 cases we examined. It is interesting to note that the proportion of cases with SMA was very similar in the United States and in the UK. In the United States, 23 union organizing campaigns resulted in employer recognition, with just over half (12) involving SMA. Among the rest of the US cases, eight involved PSMA, while member activism was insignificant (IMA) in three campaigns. In the UK, nine organizing campaigns resulted in employer recognition, of which six involved SMA and three IMA. Despite the distinct traditions of union organizing in the United States and in the UK, the proportion of SMA cases in the two countries suggests that the role of member activism in union renewal is similar. The lack of PSMA cases in the UK context is discussed in more detail below.

An examination of Table 1 reveals some interesting results. 'Hot shops', in which aggrieved workers were actively seeking union representation to gain an effective voice in the workplace, were present in six of the 12 US cases and in five of the six UK cases in which member activism played a significant role. In contrast, 'hot shops' were only present in two of the six cases in which member activism played an insignificant role. Consistent with mobilization theory, the presence of more hot shops in cases of SMA may be reflecting a greater willingness to engage in collective action when workers feel a sense of injustice, attribute blame to management and believe that collective action can make a difference (Buttigieg et al. 2008; Kelly 1998). 
Member Activism, Organizing and Union Renewal

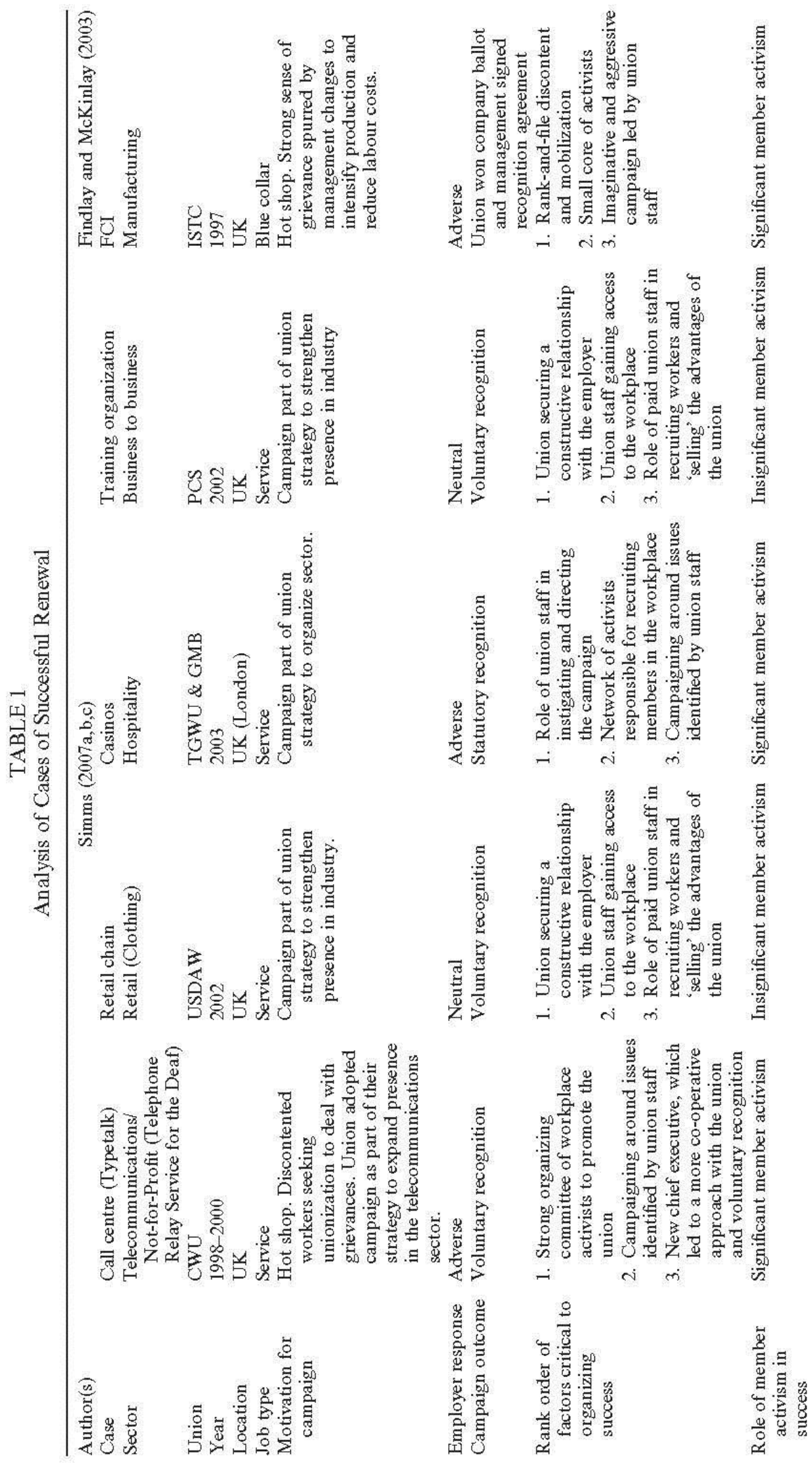




\section{British Journal of Industrial Relations}

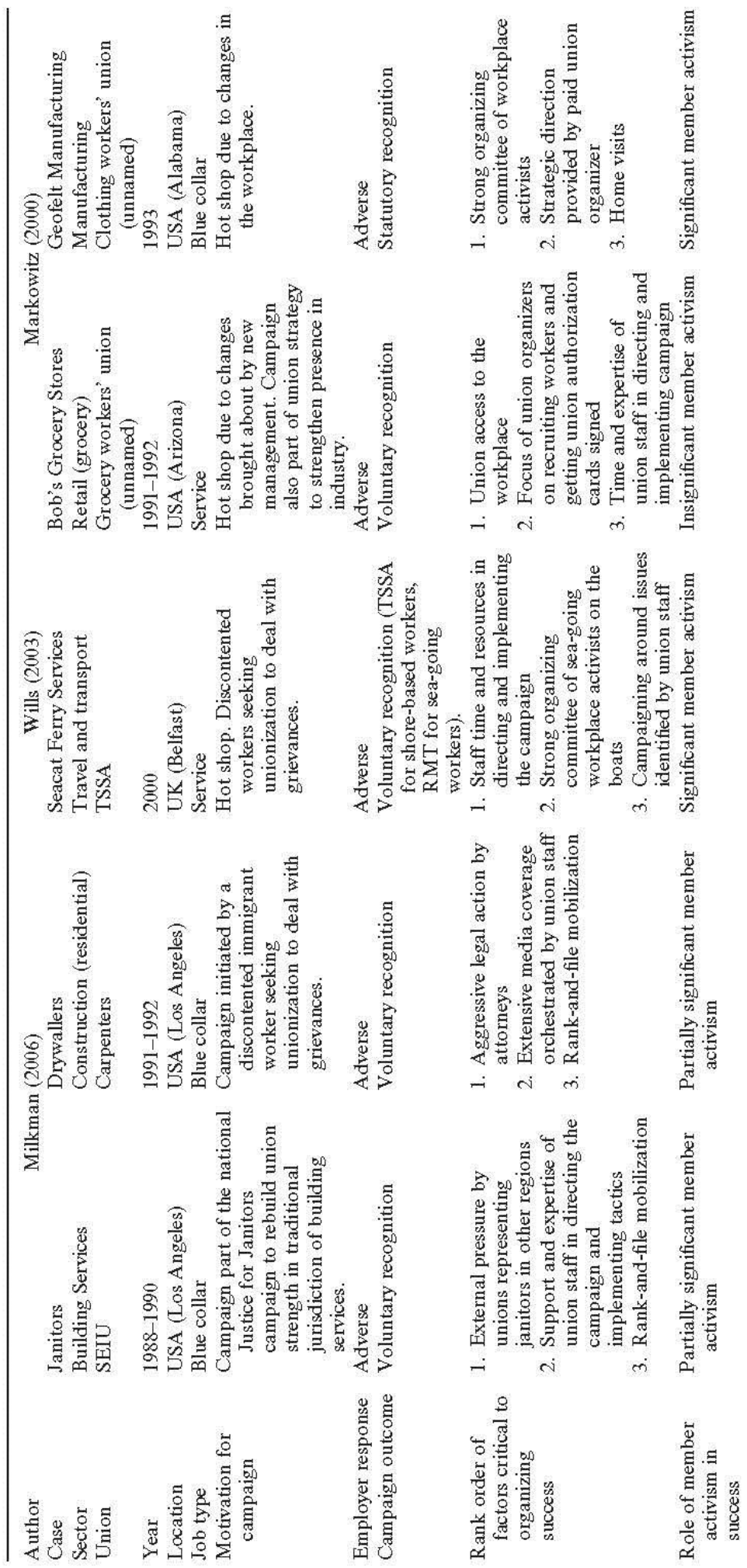


Member Activism, Organizing and Union Renewal
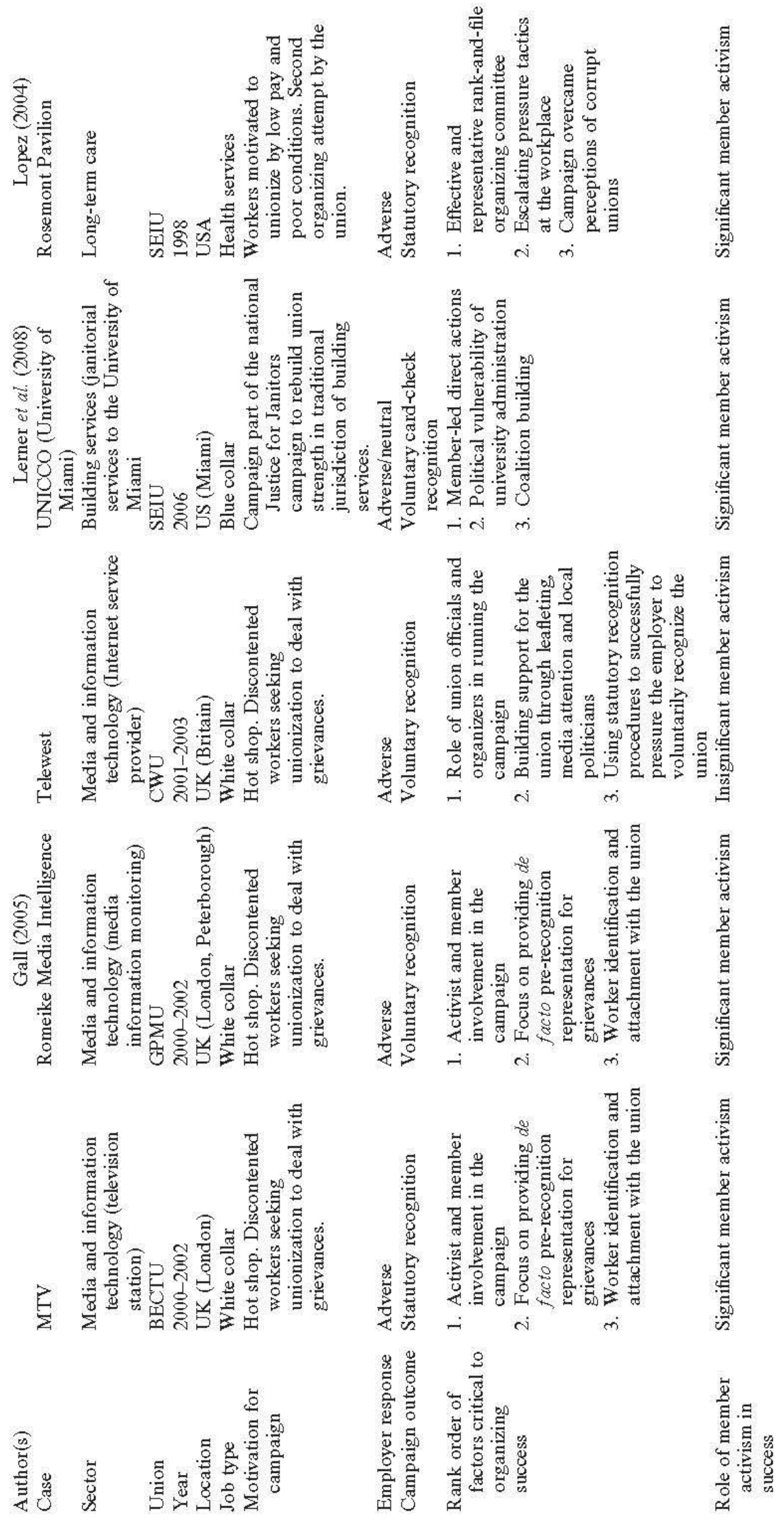
British Journal of Industrial Relations

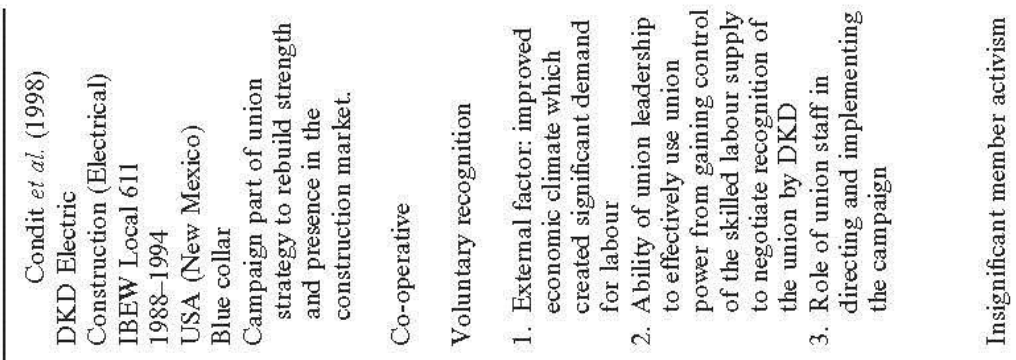
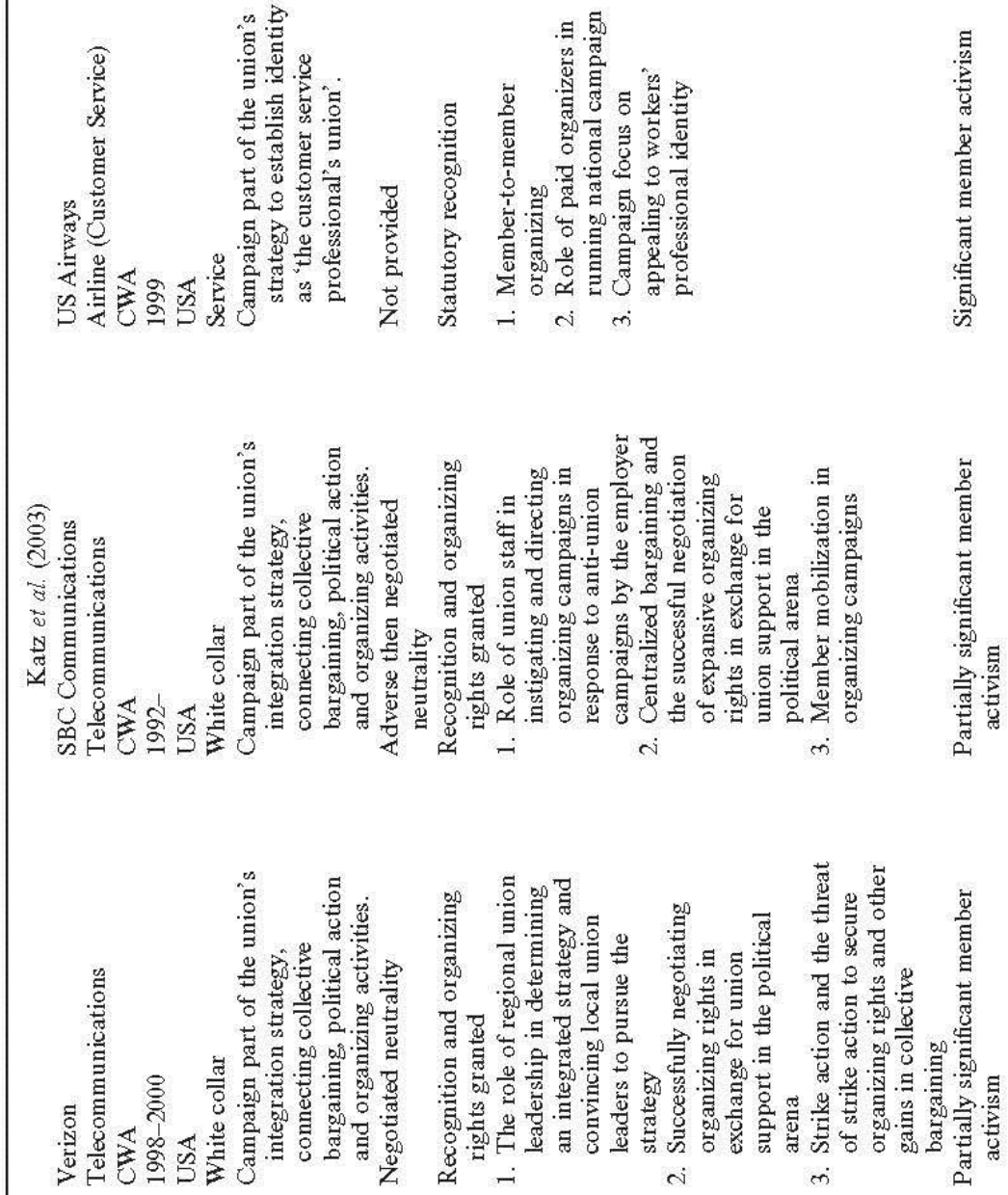

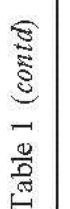

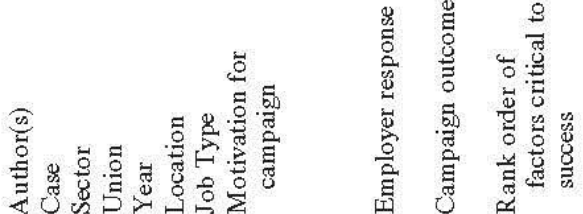

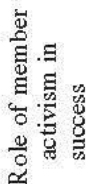


Member Activism, Organizing and Union Renewal
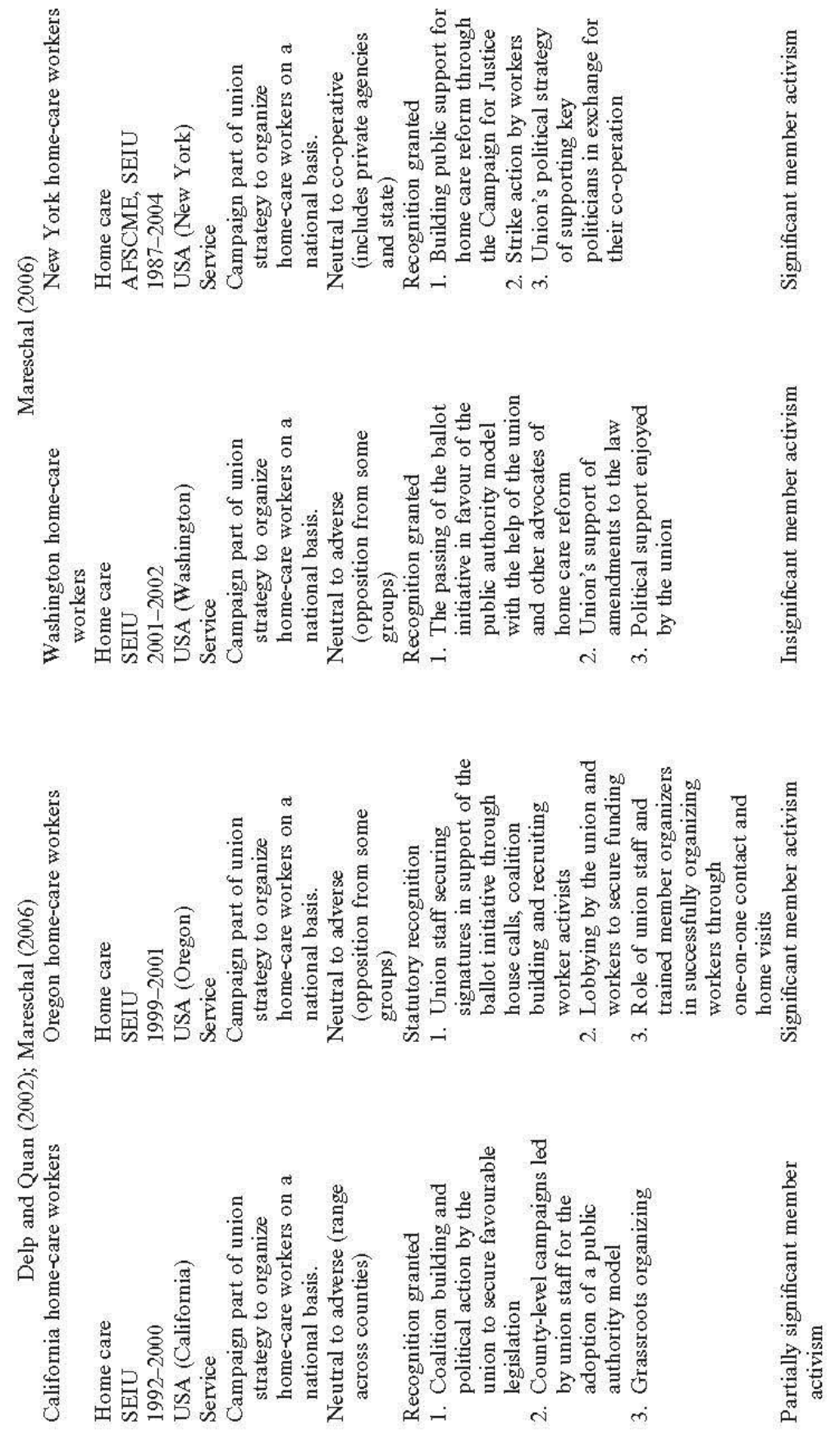

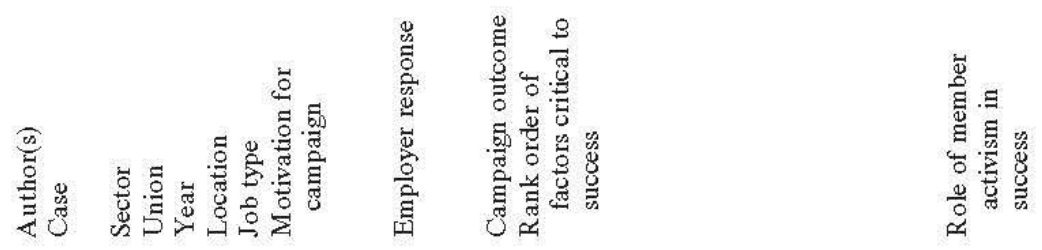


British Journal of Industrial Relations

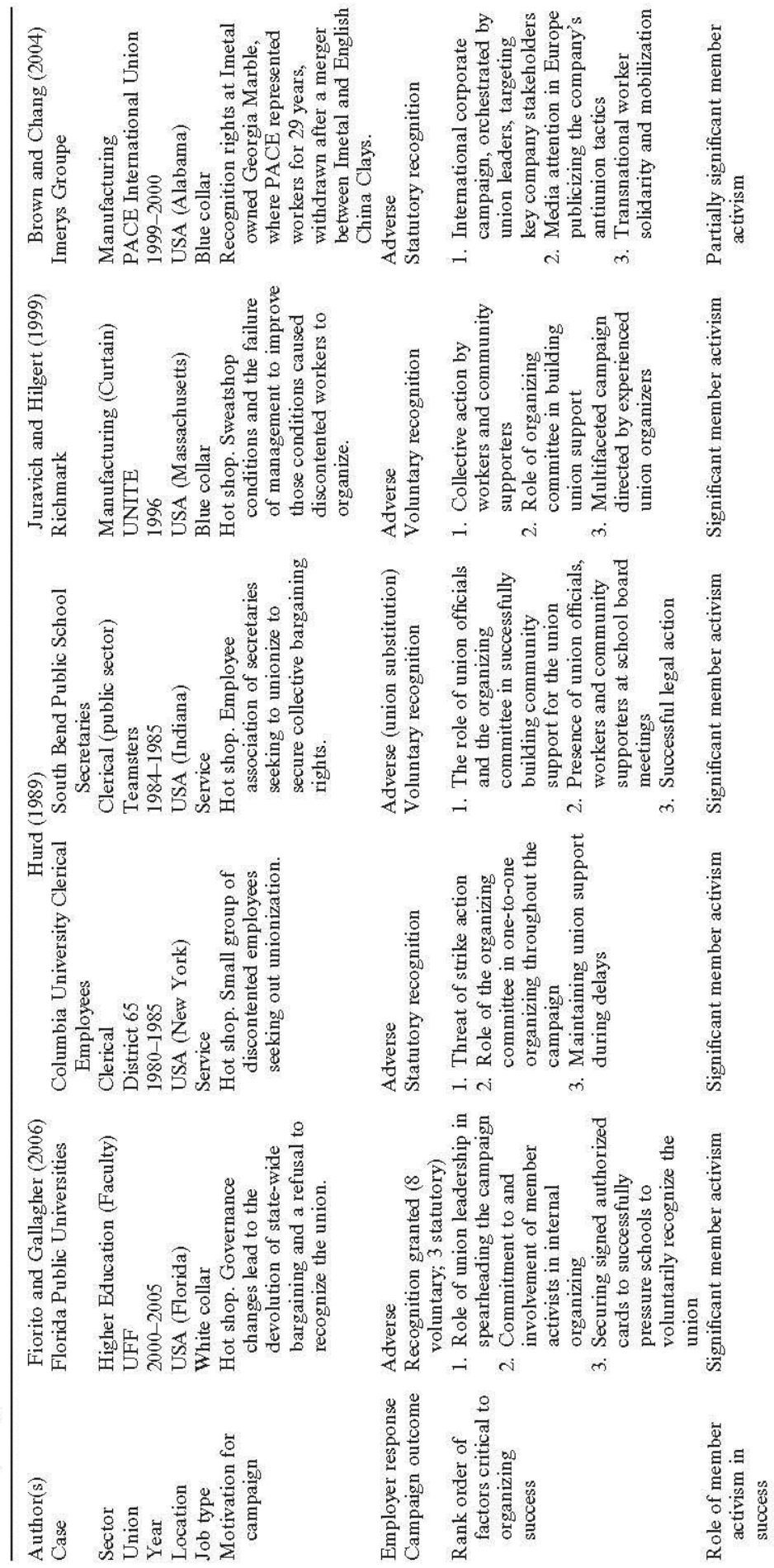




\section{Member Activism, Organizing and Union Renewal}
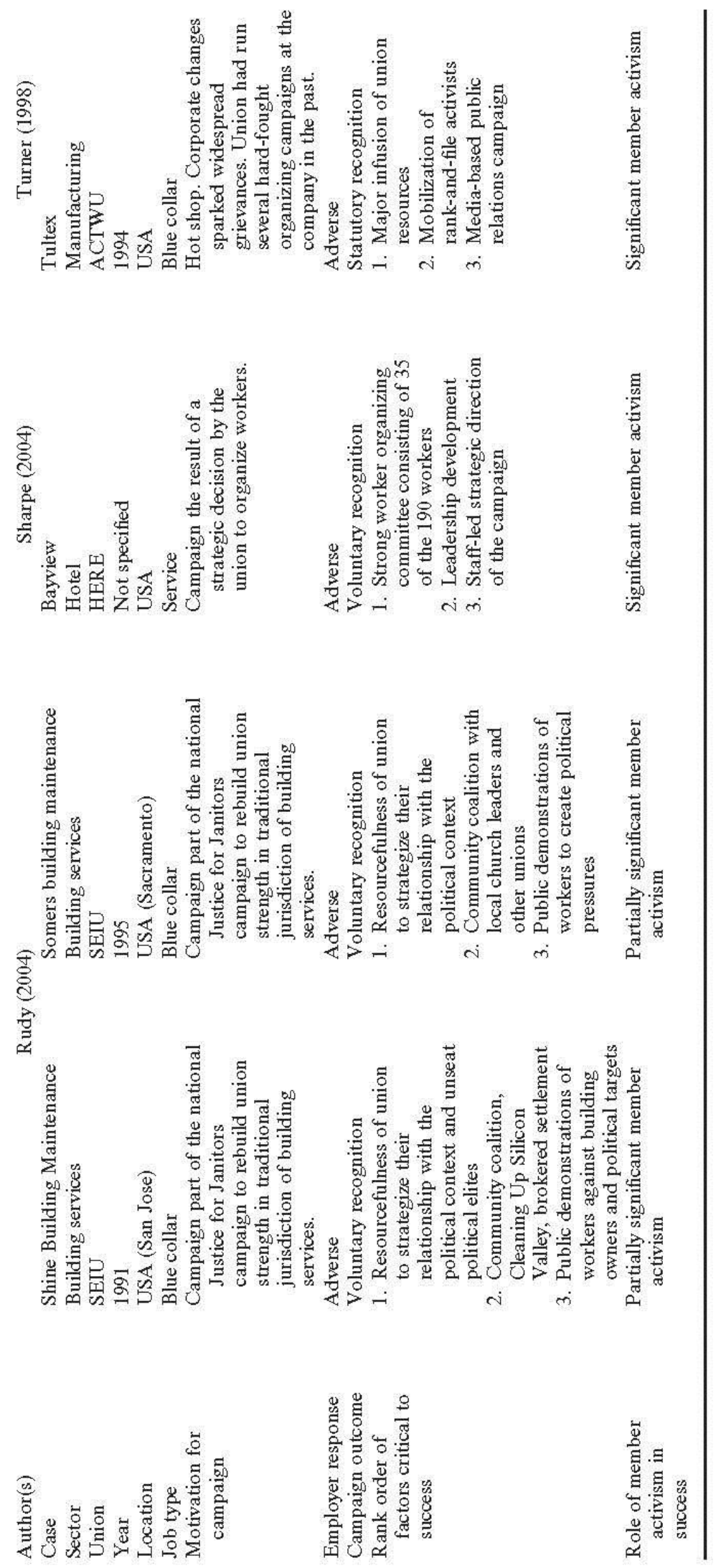
The employer's response to the organizing campaign was clearly adverse in 14 of the 18 cases of SMA compared to only two of the six cases of IMA. Half of the campaigns (five of eight) which involved PSMA faced strong employer opposition (see row 9). Higher employer opposition among the cases of SMA may be indicating that member activism is more important for organizing success or that member activism is more likely to be utilized as an organizing strategy when the employer is strongly opposed to the union. It is worth noting that an adverse response from the employer to the organizing campaign is associated with greater efforts to build member activism (i.e. Simms 2007a,b,c: Call centre; Wills 2003: Seacat Ferry Services; Markowitz 2000: Geofelt Manufacturing). This is consistent with studies that have cited a 'rebound' effect to some employer tactics and a correlation between the intensity of union and employer tactics during an organizing campaign (Bentham 2002; Bronfenbrenner 1997; Fiorito 2003).

Among the US cases of SMA, half (six) gained union recognition through statutory certification procedures while the other half (six) gained union recognition voluntarily by the employer. In the UK, more cases of SMA gained voluntary recognition than statutory recognition, four and two, respectively. In contrast, all six of the cases of IMA achieved union recognition through voluntary recognition by the employer. Likewise, seven of the eight cases with PSMA involved a non-statutory recognition procedure. The fact that voluntary recognition by the employer was found more often in cases of IMA seems to be reflecting, at least in part, the relatively stronger opposition of employers in cases of SMA.

In eight of the nine cases of statutory recognition, successful organizing campaigns involved SMA. This is not a surprising finding given that the statutory recognition procedures in both the United States and UK require a majority of workers to vote in favour of union certification. Unions that run grassroots organizing campaigns are generally more effective at identifying and articulating workplace discontent, building social cohesion, and demonstrating instrumentality of collective action - factors associated with a greater likelihood to vote for union certification (Barling et al. 1992).

Examining the range of organizing tactics reported by the original scholars, cases of SMA were much more likely to involve tactics associated with grassroots (bottom-up) organizing, and cases of IMA were much more likely to involve leadership-driven tactics, such as having union staff recruit workers. However, the only tactic that was used consistently across all types of cases was the support and expertise of union staff. Staff time, expertise and money were explicitly critical for ensuring campaign success in 23 of the cases we examined (see Table 1, row 11). While there is not enough information across the cases to determine the level and role of union staff over time, one thing is clear: the organizing campaigns in our study, for the most part, required the support and expertise of union staff to succeed. In cases of IMA, union officials and organizers were typically responsible for directing and 
implementing the organizing campaigns. This includes promoting the union and recruiting workers. Even in those cases where member activism was a salient factor in achieving organizing success, union officials often ran the organizing campaign and were responsible for identifying issues, framing grievances and determining campaign strategies. These findings are consistent with quantitative studies of union organizing campaigns that found the use of sufficient and appropriate resources, especially staff resources, a critical factor in success (Bronfenbrenner 1997; Bronfenbrenner and Hickey 2004; Fiorito et al. 1995).

Our analysis of the 12 cases where the organizing campaigns were not successful is reported in Table 2. In the United States, there were four unsuccessful cases, of which two had high levels of member activism and two had low levels. In the UK, there were eight unsuccessful cases of union organizing. Six of the unsuccessful cases in the UK exhibited low levels of member activism, while two cases had high levels of member activism. Employer resistance played a prominent role in the cases of union failure. Problems with union leadership were found in three of the four cases with high levels of member activism.

Overall, the cases of unsuccessful union organizing present a mixed picture. In at least one unsuccessful case, the original author (Lopez 2004) argues that more intensive rank-and-file tactics was the key difference between a failed and successful union organizing campaign. In the face of aggressive employer resistance, the four unsuccessful cases examined by Gall (2005) imply the same lesson. However, the unsuccessful cases also provide some evidence that SMA is not a sufficient condition for success. Four union campaigns had high levels of member activism (port truckers, family child care providers, Excell and Chungwa), but still failed to achieve employer recognition.

\section{Discussion}

What emerges from the analysis of union organizing success is a three-tier spectrum of cases in which the role of member activism ranges from an important element of union renewal to an insignificant factor in campaigns with very limited workplace activism. In the first set of cases, SMA, we find that member activism played a fundamental role in the union renewal effort. In these cases, we consider member mobilization to be both necessary and sufficient for union organizing success. In one case involving faculty from Florida public universities facing significant environmental changes, member activism was seen as critical to successful union renewal (Fiorito and Gallagher 2006). While representation rights initially existed for these workers, these rights were being challenged as a result of 
governance changes which resulted in the abolition of the statewide Board of Regents (BOR), the establishment of institutional-level Board of Trustees (BOTs) and the subsequent refusal to uphold previous recognition arrangements with the United Faculty of Florida (UFF). In response, the UFF undertook a massive 'organizing' campaign to re-establish itself. While this included signing authorization cards and gaining voluntary recognition from BOTs, it also and perhaps most importantly included internal organizing in the form of a network of member activists. Along with the role of union leadership in spearheading the campaign, member activism was identified as critical for securing recognition rights, and thus union renewal, in this case.

In the second category of cases, PSMA, we found that member mobilization was still an important part of the campaign, but success depended on other sources of bargaining power. Thus member activism was necessary but other sources of bargaining power were needed for union organizing success. For example, member activism played an important role in organizing SBC Communications, but the authors attribute successful union renewal to centralized bargaining and strategic leadership that integrated political action, bargaining and organizing activities (Katz et al. 2003). In this case, political action seems to have mattered more for union renewal than member activism.

In the third category of cases, IMA, other union strategies and institutional factors were central to organizing success. Member mobilization was neither necessary nor sufficient for union renewal. For example, in Simms' (2007c) analysis of organizing success by PCS and USDAW, she found the union's constructive relationship with management and paid staff leadership to be significant factors in success. In contrast, these campaigns featured little or no worker activism. . Similarly, in cases where unions focused on legal strategies (Telewest), staff-driven tactics (DKD) or political action (Washington Home Care Workers), such top-down approaches eclipsed workplace activism.

Whether or not member activism is both necessary and sufficient is related to the source of bargaining power and does not exclude the role of union leaders in union renewal, even in cases of SMA. There is certainly no reason to assume that SMA and a strong role for union leaders are mutually exclusive. Here, the primary question is whether the union was able to draw on internal sources of bargaining power through member activism and leverage recognition from the company. In contrast, in cases where member-based bargaining power was found to be insufficient or unnecessary, the union drew upon external sources of leverage, which were not directly dependent upon member activism. 


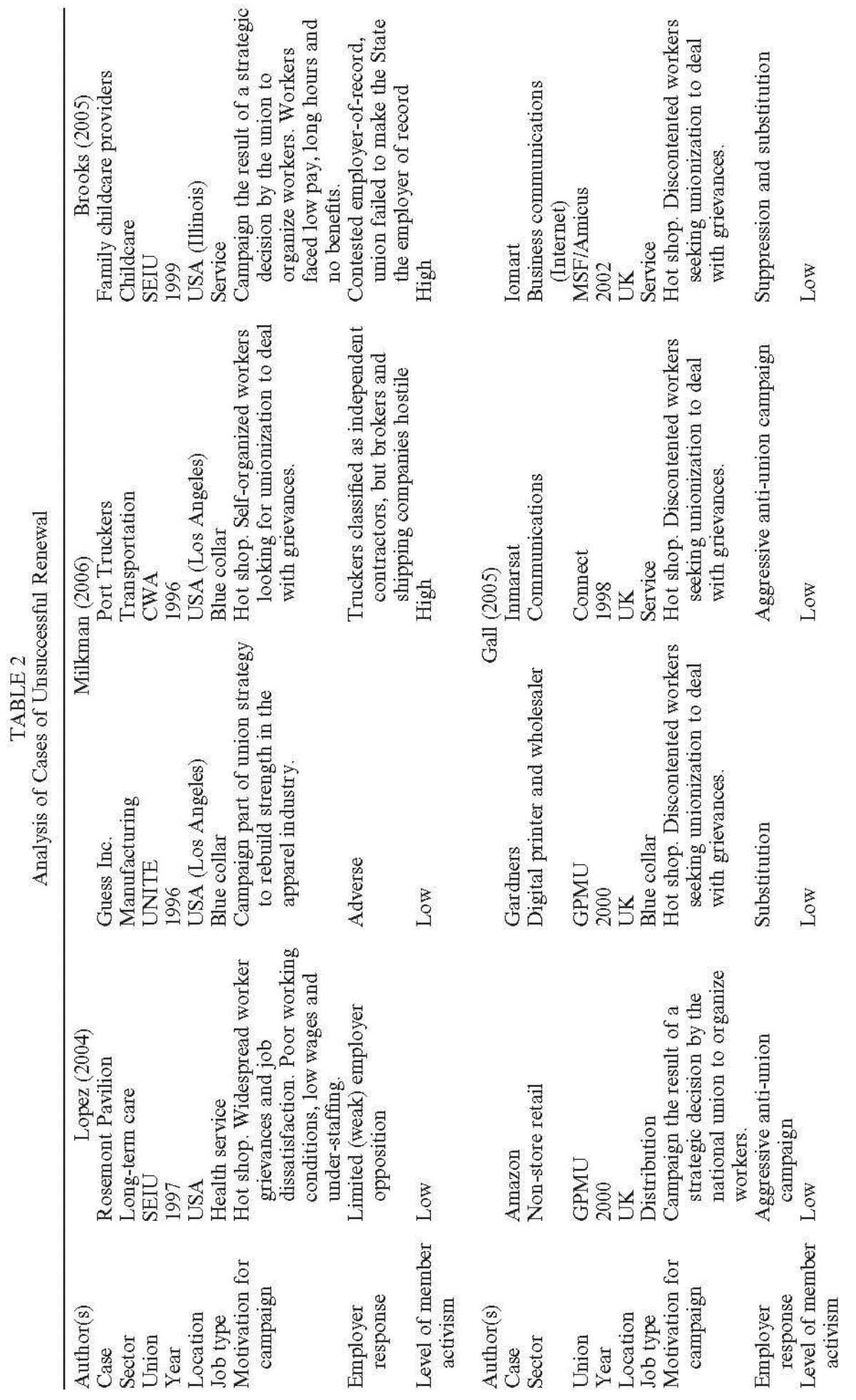


Member Activism, Organizing and Union Renewal
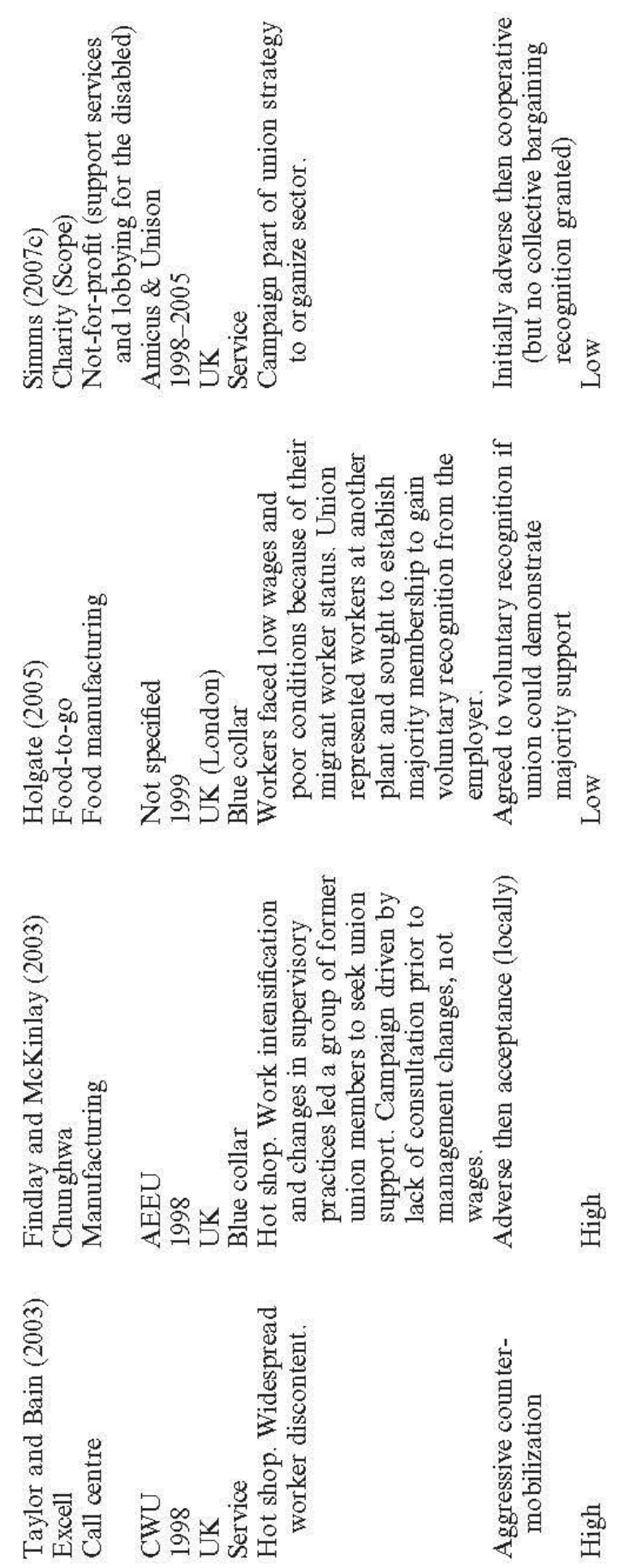

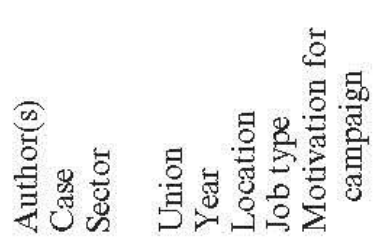

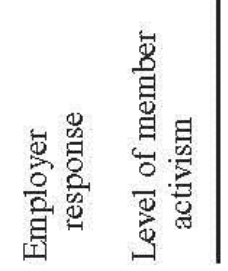


Finding both SMA and a strong role for union leaders is not surprising because union officials generally play a critical role in harnessing member-based bargaining power. Wildcat strikes, the ideal type for the exercise of bargaining power led exclusively by rank-and-file members, have become nearly extinct from the landscape of contemporary labour relations in the United States and the UK.

What of US-UK differences? When we examine the successful cases of organizing across the United States and the UK, we see that in the UK sample of cases, scholars recorded a more bifurcated presence of member activism in the campaigns studied. Member activism was either significant (six cases) or insignificant (three cases). There were no studies of PSMA, organizing campaigns in which the union combined member activism with other sources of leverage to compel employer recognition. There are two likely explanations for this difference between the US and UK cases. First, the case reports suggest that the strategic approach towards voluntary recognition differs significantly between the UK and the United States. Voluntary employer recognition in the US cases (Janitors, Drywallers, Richmark) was coerced from an otherwise hostile employer. As reflected in the UK campaigns, a cooperative, partnership approach to gaining employer recognition is at odds with the generally adversarial nature of member activism. Second, statutory recognition procedures are a relatively recent development in the UK, invoked in only two of the nine cases reviewed in this study. In contrast, US union organizing strategies have faced ballot-based recognition procedures since the passage of the Wagner Act in 1935. As a result, member activism has traditionally played a central role in union organizing efforts in the United States and remains prevalent even in campaigns that draw upon other sources of bargaining power.

Across both the US and UK cases, the data suggest that member activism is more associated with union success than loss. Still, depending on the context of each particular campaign, member activism was not consistently necessary for success, nor was it always sufficient. Thus, while the results of our study certainly do not negate the importance of member activism, they do call into question the claims that member activism is fundamental to union renewal.

What reasons can be ascribed to why member activism is not as important to union renewal as previously believed? Why do we not see a consistent link between union member activism and union renewal in the cases that we have selected? Why is member activism not more critical than our findings show us? We examine potential explanations below.

First, it is possible that we fail to find a more critical role for member activism in union renewal efforts because we use a limited definition of renewal, that is, organizing campaigns resulting in union recognition. Renewal is a broader construct, and includes many different strategies. Second, it may be 
that the value of member activism is best understood after the organizing campaign, once union structures have successfully been established.

In support of this, Weikle et al. (1998) caution against the use of the organizing model during organizing campaigns and note that 'although messages about empowerment and self-reliance may be excellent for union members and members of the local's administration, they may not be totally effective with workers during the middle of a campaign or as part of the organizing strategy' (p. 211). Third, it is possible that our methodology is at fault as we are using judgement to characterize case studies that reflect authors' interpretations of complex phenomena. Note that the case studies do not share a common analytic framework, such that slight differences in the research focus may result in significant variation in case analysis. For example, there is a marked contrast in the analyses of the factors contributing to the labour movement's largest organizing success in the second half of the twentieth century-homecare workers in California. Both studies (Delp and Quan 2002; Mareschal 2006) identify the critical roles that SEIU's legislative initiatives and coalition building played in the campaign. Delp and Quan (2002) found that grassroots organizing formed the foundation of the campaign, while policy change initiatives were a tool to make the campaign possible, and coalition building provided critical leverage. In contrast, Mareschal (2006) conducted a four-case comparison and found grassroots activism and member mobilization important in the Oregon and New York campaigns, but not in California and Washington. The focus of different case-study writers thus could explain some of our results, although we hope that our interpretation of the cases mitigates this possibility.

Fourth, it is possible that conceptualizing organizing success as winning recognition is a limited conception. Simms (2007a) identifies three measures of organizing effectiveness: the establishment of union structures, the influence of union structures and the sustainability of union structures over time. While the findings of our study do not indicate a consistent role for member activism in organizing campaigns and the establishment of union structures, a closer examination of the other two measures of organizing effectiveness may give us a better idea of the role, if any, of member activism in organizing success and thus, union renewal. These are questions for future research.

Finally, and perhaps most compellingly, it might be that the debate over the role of member activism in union renewal is misplaced. Efforts to reverse the decline of union density and influence are essentially concerned with rebuilding bargaining power. Membership activism and collective solidarity do not consistently translate into sufficient bargaining power to reverse labour's decline. Member activism is but one factor that can potentially reconstitute union bargaining power. Strategic innovations, leadership, institutional context and employer resistance are also critical factors shaping 
union bargaining power. While union strategies, particularly when used as part of a comprehensive campaign, have been shown to be critical to organizing success (Bronfenbrenner 1997; Bronfenbrenner and Hickey 2004), context and employer resistance are still critical factors to the outcome. As Simms (2007c) notes, 'choices about the organizing methods reflect a complex interaction of the union's policies and practices and the employer's policies and practices' (p. 129). In this way, the methods used in any given organizing campaign depend on a whole host of factors and no strategy or prefabricated set of strategies will unequivocally lead to success. The prevalence and success of any particular organizing strategy will depend on the union, the employer and the workers being organized. This may help to explain why member activism does not appear to be critical in every case of organizing success. Depending on the union's philosophy and past practices, they may be more or less likely to use certain methods for organizing. This may or may not include member activism.

Moreover, unions adapt their campaign strategies and methods of organizing to the particular circumstances in which they find themselves. Accordingly, the same union in two contexts may use different means to achieve the same ends. This was clear in some of the cases of organizing success that we examined. For example, the SEIU used different methods to organize homecare workers across regions, with member activism playing a more critical role in securing organizing success in Oregon and New York than in other regions (Mareschal 2006). The idea that unions adapt their organizing strategies to the particular context they are facing may also help to explain why organizing campaigns that were strongly opposed by the employer were most often characterized by SMA in our study. Unions may choose to use member activism as an organizing strategy in campaigns that are contested by the employer while relying primarily on union staff for organizing in campaigns that do not involve employer opposition. Top-down organizing strategies may focus on neutralizing employer opposition (card check/neutrality recognition agreements) or union staff may seek recognition directly from the employer (the business agent model particularly relevant in the construction trades) in the United States or the partnership model in the UK.

In addition, the importance of member activism certainly varies depending on whether the union pursues a statutory or non-statutory recognition procedure. If the union pursues a statutory certification procedure, factors associated with increasing individual participation and loyalty to the union are central to the campaign. In effect, statutory certification mechanisms provide a democratic alternative to pure union bargaining power. If the union does not have sufficient bargaining power to compel employer recognition, but does enjoy majority support in an appropriate bargaining unit, the union can still achieve statutory certification. However, as research into lower first contract success 
rates suggest (Bronfenbrenner and Hickey 2004; Ferguson 2008), the problem of union bargaining power emerges once again during contract negotiations.

An interesting paradox arises when union commitment is, at least partially, disassociated from bargaining power under state regulated, democratic certification procedures. The statutory procedures that provide a democratic alternative to pure bargaining power may have a detrimental effect on union commitment. As Gall (2005) asserts, a union's focus on quantitative measures of worker support comes at 'the detriment of the more qualitative aspects of degree of attachment and workplace organization' (p. 53). Thus, union organizing under the Employment Relations Act of 1999 is about winning the 'numbers game' and has become less concerned with building and exercising bargaining power. Gall found that 'industrial action was not part of any union's tactical armoury and planning to gain union recognition' (p. 54).

Thus, a number of potential explanations exist for not finding a stronger link between activism and renewal in our cases, which should be investigated in future research.

\section{Conclusion}

Based on an analysis of 32 detailed case studies where union renewal is defined in terms of increasing membership through new organizing success, we find that member activism is not as critical as previously expected for successful union renewal. Rather, we find that the link between member activism and union renewal is neither clear nor consistent. Indeed our analysis suggests that union renewal is more closely linked with the ability of unions to (re)generate bargaining power. In 18 out of 32 successful organizing cases, member activism and mobilization was the primary source of union bargaining power. In these cases, activism appeared to have a direct causal link with revitalization. In eight other cases, member activism, by itself, did not generate sufficient bargaining power to compel employer recognition. In six cases, where unions had sufficient bargaining power through other tactics or from other sources, member activism played an insignificant role in the successful union renewal effort. Thus, member activism emerges as neither a necessary nor a sufficient source of bargaining power, but is dependent upon a host of strategic and institutional factors. The fundamental issue for union renewal is not activism, but bargaining power. There are complex and uneven linkages between member activism and union bargaining power. Thus, member activism is a critical component to some, but not all, successful efforts at union renewal. 
Our analysis provides additional insight into the debate over top-down versus bottom-up strategies for union renewal. Namely, we find some support for the growing number of scholars who argue that the factors contributing to successful union renewal include a combination of grassroots and leadership-driven strategies tailored to the particular features of a campaign (see Bach and Givan 2008; Bronfenbrenner and Hickey 2004; Juravich and Bronfenbrenner 1999; Milkman 2006: 150-86; Sharpe 2004). Depending on the specific context, either grassroots or leadership-driven strategies, or both, may be critical for success. At the same time, top-down factors, such as the role of union staff in directing and implementing organizing campaigns, seem to be universally important across the cases, regardless of context. In this way, leadership-driven strategies may be more critical for successful union renewal and thus deserving of more attention from scholars and practitioners alike. The importance of union leadership in renewal has been noted by others as well (Fiorito 2004; Voss and Sherman 2000). Scholars who equate union renewal with 'democratization' (Fairbrother et al. 2007), which creates a more participative union membership, also acknowledge that new leadership and the ability to build power are important factors for renewal.

Our article raises several questions for future research regarding the importance of rank-and-file activism in union renewal. We know now that activism appears to be more important in the case of 'hot shops' and where there was an adverse employer reaction to the organizing campaign. But future research needs to look at whether member activism plays a more critical role in achieving influence in the workplace once union structures have been established and/or whether member activism is important for sustaining union structures in the workplace and influencing management decisions over time. Another unanswered question is whether member activism is important in broader conceptions of union renewal such as political action or coalition building. Accordingly, while the findings of our study do not provide support for the notion that member activism is a 'fundamental issue for all conceptions of union renewal' (Gall and Fiorito 2007: 11), we need more research to provide a better understanding of when, under what conditions and under what structural rules worker activism matters for the renewal of labour. Such research should give consideration to the context of union bargaining power and examine the role of member activism in reconstituting that power. There is a plethora of research questions for labour researchers here. 
Final version accepted on 18 February 2009.

\section{Acknowledgements}

We are grateful to Jack Fiorito and Rebecca Givan for helpful comments on earlier versions of the article, and to Gregor Gall, Daniel Gallagher, Melanie Simms and Donna Buttigieg for inspiration at the EAWOP conference, Stockholm.

\section{References}

Bach, S. and Givan, R. (2008). 'Public service modernization and trade union reform: towards managerial led renewal?' Public Administration, 86 (2): 523-39.

Bamberger, P. and Kluger, A. (1999). 'The antecedents and consequences of union commitment: a meta-analysis'. Academy of Management Journal, 42 (3): 304-18.

Barling, J., Fullagar, C. and Kelloway, K. (1992). The Union and Its Members: A Psychological Approach. New York: Oxford University Press.

Behrens, M., Hamann, K. and Hurd, R. (2004). 'Conceptualizing labour union revitalization'. In C. Frege and J. Kelly (eds.), Varieties of Unionism: Strategies for Union Revitalization in a Globalizing Economy. London: Oxford University Press, pp. 11-30.

Bentham, K. J. (2002). 'Employer resistance to union certification: a study of eight Canadian jurisdictions'. Relations Industrielles/Industrial Relations, 57 (1): 159-87.

Bronfenbrenner, K. (1997). 'The role of union strategies in NLRB certification elections'. Industrial and Labor Relations Review, 50 (2): 196-212.

- - and Hickey, R. (2004). 'Changing to organize: a national assessment of union organizing strategies'. In R. Milkman and K. Voss (eds.), Rebuilding Labor: Organizing and Organizers. Ithaca, NY: Cornell University Press/ILR Press, pp. 17-61.

- - and Juravich, T. (1998). 'It takes more than house calls: organizing to win with a comprehensive union building strategy'. In K. Bronfenbrenner, S. Friedman, R. Hurd, R. Oswald, and R. Seeber (eds.), Organizing to Win: New Research on Union Strategies. Ithaca, NY: Cornell University Press, pp. 18-36.

Brooks, F. (2005). 'New turf for organizing: family child-care providers'. Labor Studies Journal, 29 (4): 45-64.

Brown, E. and Chang, T. (2004). 'PACE International Union vs. Imerys Groupe: an organizing campaign case study'. Labor Studies Journal, 29 (1): 21-41.

Buttigieg, D. M., Deery, S. J. and Iverson, R. D. (2008). 'Union mobilization: a consideration of the factors affecting the willingness of union members to take industrial action'. British Journal of Industrial Relations, 46 (2): 248-67.

Condit, B., Davis, T., Grabelsky, J. and Kotler, F. (1998). 'Construction organizing: a case study of success'. In K. Bronfenbrenner, S. Friedman, R. W. Hurd, R. A. Oswald and R. L. Seeber (eds.), Organizing to Win: New Research on Union Strategies. Ithaca, NY: Cornell University Press, pp. 309-19. 
De Turberville, S. (2004). 'Does the “organising model” represent a credible union renewal strategy?’ Work, Employment and Society, 18 (4): 775-94.

Delp, L. and Quan, K. (2002). 'Homecare worker organizing in California: an analysis of a successful strategy'. Labor Studies Journal, 27 (1): 1-23.

Eaton, A. E. and Kriesky, J. (2001). 'Union organizing under neutrality and card check agreements'. Industrial and Labor Relations Review, 55 (1): 42-59.

Fairbrother, P. (1989). Workplace Unionism in the 1980s: A Process of Renewal. London: Workers' Educational Association.

- - (2000). Trade Unions at the Crossroads. New York: Mansell.

- - and Yates, C. (2003). Trade Unions in Renewal: A Comparative Study. New York: Continuum.

- - Williams, G., Barton, R., Gibellieri, E. and Tropeoli, A. (2007). 'Unions facing the future: questions and possibilities'. Labor Studies Journal, 31 (4): 48-9.

Ferguson, J. (2008). 'The eyes of needles: sequential model of union organizing drives, 1999-2004'. Industrial and Labor Relations Review, 62 (1): 3-21.

Findlay, P. and McKinlay, A. (2003). 'Organizing in electronics: recruitment, recognition, and representationshadow shop stewards in Scotland's “Silicon Glen” '. In G. Gall (ed.), Union Organizing: Campaigning for Trade Union Recognition. London: Routledge, pp. 114-32.

Fiorito, J. (2003). 'Union organizing in the United States'. In G. Gall (ed.), Union Organising: Campaigning for Trade Union Recognition. London: Routledge, pp. 191-210.

- - (2004). 'Union renewal and the organizing model in the United Kingdom'. Labor Studies Journal, 29 (2): $21-53$.

- - and Gallagher, V. C. (2006). 'Renewal in the United Faculty of Florida: class war in paradise?' Labor Studies Journal, 31 (3): 39-64.

- - Gallagher, D. G. and Fukami, C. V. (1988). 'Satisfaction with union representation'. Industrial and Labor Relations Review, 41 (2): 294-307.

- - Jarley, P. and Delaney, J. T. (1995). 'National union effectiveness in organizing: measures and influences'. Industrial and Labor Relations Review, 48 (4): 613-35.

Freeman, R. and Kleiner, M. (1990). 'Employer behaviour in the face of union organizing drives'. Industrial and Labor Relations Review, 43 (4): 351-65.

Fullagar, C., Gallagher, D. G., Clark, P. F. and Caroll, A. (2004). 'Union commitment and participation: a ten-year longitudinal study'. Journal of Applied Psychology, 89 (4): 730-7.

Gall, G. (2005). 'Organizing non-union workers as trade unionists in the "new economy” in Britain'. Economic and Industrial Democracy, 26: 41-63.

- - and Fiorito, J. (2007). 'Union commitment and union renewal: something old, something new, something borrowed, and the blues'. Paper presented at the EAWOP Conference, Stockholm, Sweden, May. 
Gallagher, D. G. and Strauss, G. (1991). ‘Union membership attitudes and participation'. In G. Strauss, D. Gallagher and J. Fiorito (eds.), The State of the Unions. Madison, WI: Industrial Relations Research Association, pp. 139-74.

Gordon, M. E., Philpot, J. W., Burt, R. E., Thompson, C. A. and Spiller, W. E. (1980). 'Commitment to the union: development of a measure and an examination of its correlates'. Journal of Applied Psychology, 65 (4): 479-99.

Hartley, J. (1996). 'The "new" service sector: employment status, ideology, and trade union participation in the UK'. In P. Pasture, J. Verbeckmoes and H. De Witte (eds.), The Lost Perspective? Trade Unions between Ideology and Social Action in the New Europe. Brookfield, IL: Avebury, pp. 326-52.

Heery, E. (2003). 'Trade unions and industrial relations'. In P. Ackers and A. Wilkinson (eds.), Understanding Work and Employment. New York: Oxford University Press, pp. 278-304.

- -, Simms, M., Simpson, D., Delbridge, R. and Salmon, J. (2000). 'Organizing unionism comes to the UK'. Employee Relations, 22 (1): 38-57.

- -, Simms, M., Delbridge, R., Salmon, J. and Simpson, D. (2003). 'Trade union recruitment policy in Britain: form and effects'. In G. Gall (ed.), Union

Holgate, J. (2005). 'Organizing migrant workers: a case study of working conditions and unionization in a London sandwich factory'. Work, Employment and Society, 19 (3): 463-80.

Hurd, R. W. (1989). 'Learning from clerical unions: two cases of organizing success'. Labor Studies Journal, 14 (1): 30-51.

- - (2008). 'Neutrality agreements: innovative, controversial, and labor's hope for the future'. New Labor Forum, $17(1): 34-45$.

- - Milkman, R. and Turner, L. (2003). 'Reviving the American labour movement: institutions and mobilization'. European Journal of Industrial Relations, 9 (1):99-117.

Juravich, T. and Bronfenbrenner, K. (1999). Ravenswood: The Steelworkers' Victory and the Revival of American Labor. Ithaca, NY: Cornell University Press.

- - and Hilgert, J. (1999). 'UNITE's victory at Richmark: community-based union organizing in communities of color'. Labor Studies Journal, 24 (1): 27-41.

Katz, H. C., Batt, R. and Keefe, J. H. (2003). 'The revitalization of the CWA: integrating collective bargaining, political action, and organizing'. Industrial and Labor Relations Review, 56 (4): 573-89.

Kelly, J. E. (1998). Rethinking Industrial Relations: Mobilization, Collectivism, and Long Waves. New York: Routledge.

- - and Frege, C. (2004). Varieties of Unionism: Strategies for Union Revitalization in a Globalizing Economy. Oxford: Oxford University Press. 
Kumar, P. and Schenk, C. (2006). 'Union renewal and organizational change: a review of the literature'. In P. Kumar and C. Schenk (eds.), Paths to Union Renewal: Canadian Experiences. Peterborough, ON: Broadview Press Ltd, pp. 29-60.

Kuruvilla, S. C. and Fiorito, J. (1994). 'Who will help? Willingness to work for the union'. Relations Industrielles/Industrial Relations, 49 (3): 548-75.

Lerner, S. (2003). 'An immodest proposal: a new architecture for the house of labor'. New Labor Forum, 12 (2): $9-$ 30.

- - , Hurst, J. and Adler, G. (2008). 'Fighting and winning in the outsourced economy: justice for janitors at the University of Miami'. In A. Bernhardt, H. Boushey, L. Dresser and C. Tilly (eds.), The Gloves-off Economy: Workplace Standards at the Bottom of America's Labor Market. Champaign, IL: Labor and Employment Relations Association, pp. 243-68.

Lopez, S. (2004). 'Overcoming legacies of business unionism: why grassroots organizing tactics succeed'. In R. Milkman and K. Voss (eds.), Rebuilding Labor: Organizing and Organizers in the New Union Movement. Ithaca, NY: Cornell University Press/ILR Press, pp. 114-32.

McShane, S. (1986). 'The multidimensionality of union participation'. Journal of Occupational Psychology, 59: 17787.

Mareschal, P. M. (2006). 'Innovation and adaptation: contrasting efforts to organize home care workers in four states'. Labor Studies Journal, 31 (1): 25-49.

Markowitz, L. (2000). Worker Activism after Successful Union Organizing. New York: M.E. Sharpe.

Martinello, F. and Yates, C. (2004). 'Union and employer tactics in Ontario organizing campaigns'. In D. Lewin and B. Kaufman (eds.), Advances in Industrial and Labor Relations Volume 13. New York: Elsevier, pp. 157-90.

Metzgar, J. (1991). 'Introduction'. Labor Research Review, 17: vi-viii.

Milkman, R. (2006). L.A. Story: Immigrant Workers and the Future of the U.S. Labor Movement. New York: Russell Sage Foundation.

Muehlenkamp, R. (1991). 'Organizing never stops'. Labor Research Review, 17: 1-5.

Nissen, B. (1998). 'Utilizing the membership to organize the unorganized'. In K. Bronfenbrenner, S. Friedman, R. W. Hurd, R. A. Oswald and R. L. Seeber (eds.),Organizing to Win. Ithaca, NY: Cornell University Press, pp. 13549.

NLRB (2004-2006). 'NLRB annual reports'. Available at: http://www.nlrb.gov/ publications/reports/annual_reports.aspx.

Olson, M. (1965). The Logic of Collective Action: Public Goods and the Theory of Groups. New York: Harvard University Press.

Parker, M. and Gruelle, M. (1999). Democracy is Power: Rebuilding Unions from the Bottom up. Detroit, MI: Labor Notes. 
Penney, R. (2004). 'Workers against unions: union organizing and anti-union counter mobilization'. In R. Milkman and K. Voss (eds.), Rebuilding Labor: Organizing and Organizers. Ithaca, NY: Cornell University Press/ILR Press, pp. 88-113.

Peters, R. and Merrill, T. (1998). 'Clergy and religious persons' roles in organizing at O'Hare Airport and St. Joseph Medical Center'. In K. Bronfenbrenner, S. Friedman, R. Hurd, R. Oswald and R. Seeber (eds.), Organizing to Win: New Research on Union Strategies. Ithaca, NY: Cornell University Press, pp. 164-78.

Riddell, C. (2004). 'Union certification success under voting versus card check procedures'. Industrial and Labor Relations Review, 57 (4): 493-517.

Rudy, P. (2004). “ "Justice for janitors” not "compensation for custodians” '. In R. Milkman and K. Voss (eds.), Rebuilding Labor: Organizing and Organizers in the New Union Movement. Ithaca, NY: Cornell University Press/ILR Press, pp. 133-49.

Scott, J. C. Jr (1957). 'Membership and participation in voluntary associations'. American Sociological Review, 22 (3): 315-26.

Sharpe, T. (2004). 'Union democracy and successful campaigns: the dynamics of staff authority and worker participation in an organizing union'. In R. Milkman and K. Voss (eds.), Rebuilding Labor: Organizing and Organizers in the New Union Movement. Ithaca, NY: Cornell University Press/ILR Press, pp. 62-87.

Simms, M. (2007a). 'What are we organising for? The influence of trade union tactics on greenfield organising campaign effectiveness'. Paper presented at the EAWOP Conference, Stockholm, Sweden, May.

- - (2007b). 'Interest formation in greenfield union organising campaigns'. Industrial Relations Journal, 38 (5): 439-54.

- - (2007c). 'Managed activism: two union organising campaigns in the not-for-profit sector'. Industrial Relations Journal, 38 (2): 119-35.

Snape, E., Redman, T. and Chen, A. (2000). 'Commitment to the union: a survey of research and the implications for industrial relations and trade unions'. International Journal of Management Reviews, 2 (3): 205-30.

Stinson, J. and Ballantyne, M. (2006). 'Union renewal and CUPE'. In P. Kumar and C. Schenk (eds.), Paths to Union Renewal: Canadian Experiences. Peterborough, ON: Broadview Press Ltd, pp. 145-60

Sverke, M. and Kuruvilla, S. (1996). 'New conceptualizations: development and test of an integrated theory'. Journal of Organizational Behavior, 16: 505-33.

Tait, V. (2005). Poor Workers' Unions: Rebuilding Labor from Below. New York: South End Press.

Taylor, P. and Bain, P. (2003). 'Call center organizing in adversity: from Excell to Vertex'. In G. Gall (ed.), Union Organizing: Campaigning for Trade Union Recognition. London: Routledge, pp. 153-72.

Turner, L. (1998). 'Rank-and-file participation in organizing at home and abroad'. In K. Bronfenbrenner, S. Friedman, R. W. Hurd, R. A. Oswald and R. L. Seeber (eds.), Organizing to Win: New Research on Union Strategies. Ithaca, NY: Cornell University Press, pp. 123-34. 
- - and Hurd, R. W. (2001). 'Building social movement unionism: the transformation of the American labor movement'. In L. Turner, H. C. Katz and R. W. Hurd (eds.), Rekindling the Movement: Labor's Quest for Relevance in the 21st Century. New York: Cornell University Press, pp. 9-26.

- - Katz, H. C. and Hurd, R. W. (2001). Rekindling the Movement: Labor's Quest for Relevance in the Twenty-First Century. Ithaca, NY: Cornell University Press.

Voss, K. and Sherman, R. (2000). 'Breaking the iron law of oligarchy: union revitalization in the American labor movement'. American Journal of Sociology, 106: 303-49.

Walsh, E. J. and Warland, R. H. (1983). 'Social movement involvement in the wake of a nuclear accident: activists and free riders in the TMI area'. American Sociological Review, 48 (6): 764-80.

Weikle, R. D., Wheeler, H. N. and McClendon, J. A. (1998). 'A comparative case study of union organizing success and failure: implications for practical strategy'. In K. Bronfenbrenner, S. Friedman, R. W. Hurd, R. A.

Oswald and R. L. Seeber (eds.), Organizing to Win: New Research on Union Strategies. Ithaca, NY: Cornell University Press, pp. 197-212.

Wills, J. (2003). 'Organizing in transport and travel: learning lessons from TSSA's Seacat campaign'. In G. Gall (ed.), Union Organizing: Campaigning for Trade Union Recognition. London: Routledge, pp. 133-52.

\section{Appendix: union acronyms}

ACTWU - Amalgamated Clothing and Textile Workers Union

AEEU - Amalgamated Electrical and Engineering Union

AFSCME - American Federation of State, County and Municipal Employees

Amicus - Merger between the Amalgamated Electrical and Engineering

Union (AEEU) and Manufacturing, Science and Finance Union (MSF)

AUT - Association of University Teachers

BECTU - Broadcasting, Entertainment, Cinematograph and Theatre Union

Carpenters - United Brotherhood of Carpenters and Joiners of America

CWU - Communication Workers Union

CWA - Communications Workers of America

District 65 - Independent union; formerly known as the Distributive Workers

GMB-General, Municipal, Boilermakers and Allied Trade Union; general trade union in Britain

GPMU — Graphical, Paper and Media Union

HERE - Hotel Employees and Restaurant Employees International Union

IBEW - International Brotherhood of Electrical Workers

ISTC - Iron and Steel Trade Corporation 
MSF - Manufacturing, Science and Finance Union

PACE - Paper, Allied-Industrial, Chemical and Energy Workers International Union

PCS - Public and Commercial Services Union

RMT - National Union of Rail, Maritime and Transport Workers

SEIU - Service Employees International Union

Teamsters - International Brotherhood of Teamsters

TGWU - Transport and General Workers Union

TSSA - Transport Salaried Staffs' Association

UDW - United Domestic Workers of America

UFF - United Faculty of Florida

Unison - Public sector union

UNITE - Union of Needletrades, Industrial and Textile Employees

USDAW - Union of Shop, Distributive and Allied Workers

'Our approach is analogous to a qualitative 'meta-analysis'.

ii According to Annual Reports of the NLRB, unions in the US won 1,195 representation elections in 2006, 1,504 representation elections in 2005 and 1,447 representation elections in 2004 (see NLRB 2004-2006).

iii The collection also includes two cases in which recognition rights previously existed but were later unilaterally revoked by the employer (see Brown and Chang 2004; Fiorito and Gallagher 2006).

iv Simms (2007a) does note that the USDAW case had much more positive outcomes, especially in terms of membership density, than PCS. According to Simms, part of the difference between the outcomes of these two top-down campaigns was that in the USDAW 'there was more evidence of workplace representatives taking on some roles representing members on minor grievances (2007a: 6). Thus, even a little member activism may have important implications for longer term success and sustainability. We appreciate and acknowledge Jack Fiorito's contribution on this point. 